\title{
How much antibiotic for cesarean section and hysterectomy: short course versus long course
}

\author{
Amol M. Valvi*, Arun R. Mahale, Pankaj N. Baravkar \\ Department of Obstetrics \& Gynecology, MIMSR Medical College, Latur, Maharashtra, India \\ Received: 16 April 2014 \\ Accepted: 4 May 2014 \\ *Correspondence: \\ Dr. Amol M. Valvi, \\ E-mail: amol.valvi@yahoo.com \\ (C) 2014 Valvi AM et al. This is an open-access article distributed under the terms of the Creative Commons Attribution \\ Non-Commercial License, which permits unrestricted non-commercial use, distribution, and reproduction in any \\ medium, provided the original work is properly cited.
}

\begin{abstract}
Background: Objective of current study was to compare cost and efficacy of short course and long course prophylactic antibiotics for hysterectomy and cesarean section.

Methods: The current study is observational study. It has two antibiotic regimens a short course and a long course and these are compared for average duration of antibiotics, average cost of antibiotics, and outcome measures such as wound infection and febrile illness. Data were analyzed using $t$ test, Chi-squared test, Epi info software used for analysis.

Results: The short course low cost regimen is as effective as more expensive long course regimen, with no significant difference of wound infections and febrile morbidity $(\mathrm{P}>0.05)$.

Conclusions: No statistical difference as regard wound infection and febrile morbidity in short course and long course of prophylactic antibiotic therapy in cesarean section and hysterectomy. There is statistical difference in antibiotic cost between two regimen, short course and long course for cesarean section and hysterectomy. The cost of antibiotic is 5.53 times less in short course regimen for cesarean section and hysterectomy when compared with long course regimen.
\end{abstract}

Keywords: Cesarean section, Hysterectomy, Short course antibiotic, Long course antibiotic, Wound infection, Febrile morbidity

\section{INTRODUCTION}

World health day is celebrated on $7^{\text {th }}$ April to mark the founding of WHO. Each year, the organization selects a key health issue, and encourages people from all ages and all backgrounds to hold events that highlight the significance of this issue for good health and well-being. World health day provide the unique opportunity for communities from across the world to come together for one day to promote action that can improve our health.

On $7^{\text {th }}$ April 2011 the WHO slogan was "Combat Antimicrobial Resistance". WHO expects everyone, policy makers and planners, the public and patients, practitioners and prescribers, pharmacist and dispensers, the pharmaceutical industries to think, act and take responsibility for combating drug resistance.
Hysterectomy and Lower Segment Cesarean Section (LSCS) are commonly done procedure in obstetrics and gynecology practice. As for any other surgical procedure, antibiotics are prescribed for these procedures too. The practices vary from place to place and often from person to person. American College of Obstetrics and Gynecology (ACOG) ${ }^{1}$ and standard textbooks ${ }^{2,3}$ advocate single dose administration of prophylactic antibiotics, but in practice antibiotics are prescribed for 7 to 10 days or even little longer. Any antibiotic is effective in clean and uncontaminated cases and choice should be therefore based on other factors, such as cost. ${ }^{4}$ Parulekar et al. concluded that single dose cefotaxime is more effective as compared to conventional 5 days gentamicin and cloxacillin combination. ${ }^{5}$ 
The present study consists of comparing a short course of antibiotics with traditional long course. The outcome measures are febrile illness and wound infection.

\section{METHODS}

The current study is an observational study.

The study has two antibiotic regimens, a short course and a long course. These are compared for average duration of antibiotics per patient, average cost of antibiotics per patient and outcome measures such as febrile illness and wound infection.

This study is carried out in Obstetrics and Gynecology indoor ward at tertiary care hospital at Latur, Maharashtra.

The department of obstetrics and gynecology has two clinical units. Till WHO slogan of the year 2011 both the units were prescribing antibiotics till the day of stitch removal.

However after this slogan one unit has changed its practice and started prescribing antibiotics for a short course of one to two days, the other unit continued to prescribe antibiotics up to day of stitch removal and little longer.

The proper duration of antimicrobial use for the prevention of post-operative surgical infection has been a subject of controversy, currently more than 40 published clinical trials are available in which the efficacy of single dose surgical prophylaxis with parenteral antimicrobials has been studied. In all trials in which single dose (short course) regimen were compared with multidose (long course), Short course regimen resulted in similar frequency of post-operative wound infection as long course. Short course antimicrobials doses, usually cephalosporin given immediately before operation or intra-operatively are effective in preventing wound infection in hysterectomies and LSCS. ${ }^{6}$

In the present study the average duration of antibiotics prescribed in days and average cost of antibiotics per patient is compared and also outcome as regard febrile morbidity, wound gape, wound discharge are compared. The cost of antibiotics is assessed by using IDR Volume XIX Issue 5. $2013 .^{7}$

The data of two regimens was compared for one year from $1 / 1 / 2013$ to $31 / 12 / 2013$. Study drug regimen were, 'Short course regimen'- inj. cefotaxime $1 \mathrm{gm} \mathrm{I.V.} \mathrm{within}$ one hour of commencement of surgery, the dose is repeated if surgery last for more than two hour. Another dose is given 12 hours after the $1^{\text {st }}$ dose in same patient. Some time in short course regimen we added inj. metronidazole $500 \mathrm{mg}$ or inj. tinidazole $800 \mathrm{mg}$.
'Long course regimen'- inj. cefotaxime 1 gm I.V. twice a day for 3 to 5 days, inj. metronidazole $100 \mathrm{ml} \mathrm{I.V.} \mathrm{thrice}$ a day and inj. gentamicin $80 \mathrm{mg}$ I.V./IM twice a day for five days. Thereafter tab. cefixime $200 \mathrm{mg}$ twice a day for 3 to 5 days. Sometimes according to patient condition other oral antimicrobials are also added which are shown in Table 1.

Approval for the study was taken from the institutional ethical committee.

Table 1: Antibiotic usage between two regimens.

\begin{tabular}{|lll|}
\hline Antibiotic & $\begin{array}{l}\text { Short } \\
\text { course } \\
\text { regimen }\end{array}$ & $\begin{array}{l}\text { Long } \\
\text { course } \\
\text { regimen }\end{array}$ \\
\hline Injectable & $\sqrt{ }$ & $\sqrt{ }$ \\
\hline Inj. cefotaxime $1 \mathrm{gm}$ & $\sqrt{ }$ & $\sqrt{ }$ \\
\hline Inj. metronidazole $100 \mathrm{ml}$ & $\times$ & $\sqrt{ }$ \\
\hline Inj. gentamicin $80 \mathrm{mg}$ & $\times$ & $\sqrt{ }$ \\
\hline $\begin{array}{l}\text { Inj. amoxicillin } 1 \mathrm{gm} \text {, clavulanic } \\
\text { acid } 0.2 \text { gm }\end{array}$ & $\sqrt{ }$ & $\times$ \\
\hline Inj. tinidazole $400 \mathrm{mg}$ & $\times$ & $\sqrt{ }$ \\
\hline Inj. ceftriaxone $1 \mathrm{gm}$ & $\times$ & $\sqrt{ }$ \\
\hline Inj. amikacin & $\times$ & $\sqrt{ }$ \\
\hline Inj. meropenem & & \\
\hline Oral antibiotics & $\sqrt{ }$ & $\sqrt{ }$ \\
\hline Tab. cefixime $200 \mathrm{mg}$ & $\times$ & $\sqrt{ }$ \\
\hline Cap. amoxicillin + clavulanic acid & $\times$ & $\sqrt{ }$ \\
\hline Cap. amplus & $\times$ & $\sqrt{ }$ \\
\hline Tab. azithromycin & $\times$ & $\sqrt{ }$ \\
\hline Cap. amoxicillin & & \\
\hline
\end{tabular}

\section{RESULTS}

Total 305 patients were recruited for the study. 9 patients from hysterectomy and 16 patients from LSCS had to be excluded from the final analysis. The case histories of these patients could not be traced, so 117 cases of hysterectomies and 163 cases of LSCS were available for final analysis (Figure 1).

Following short course antibiotic therapy and long course antibiotic therapy the incidence of fever, wound infection did not differ significantly in both regimens (Table 5, 6 \& 7). Some patients of short course regimens developed fever on post-operative day 3 and day 4 with no surgical site of infection identified, fever subsided with Tab. Paracetamol and no antibiotic therapy was required.

A total 280 patients out of 305 patients were compared for total cost of antibiotic, average cost of antibiotic per patients, and average duration of antibiotic per patients and outcome measures such as wound infection and febrile illness between short course regimen and long course regimen (Table 2). 


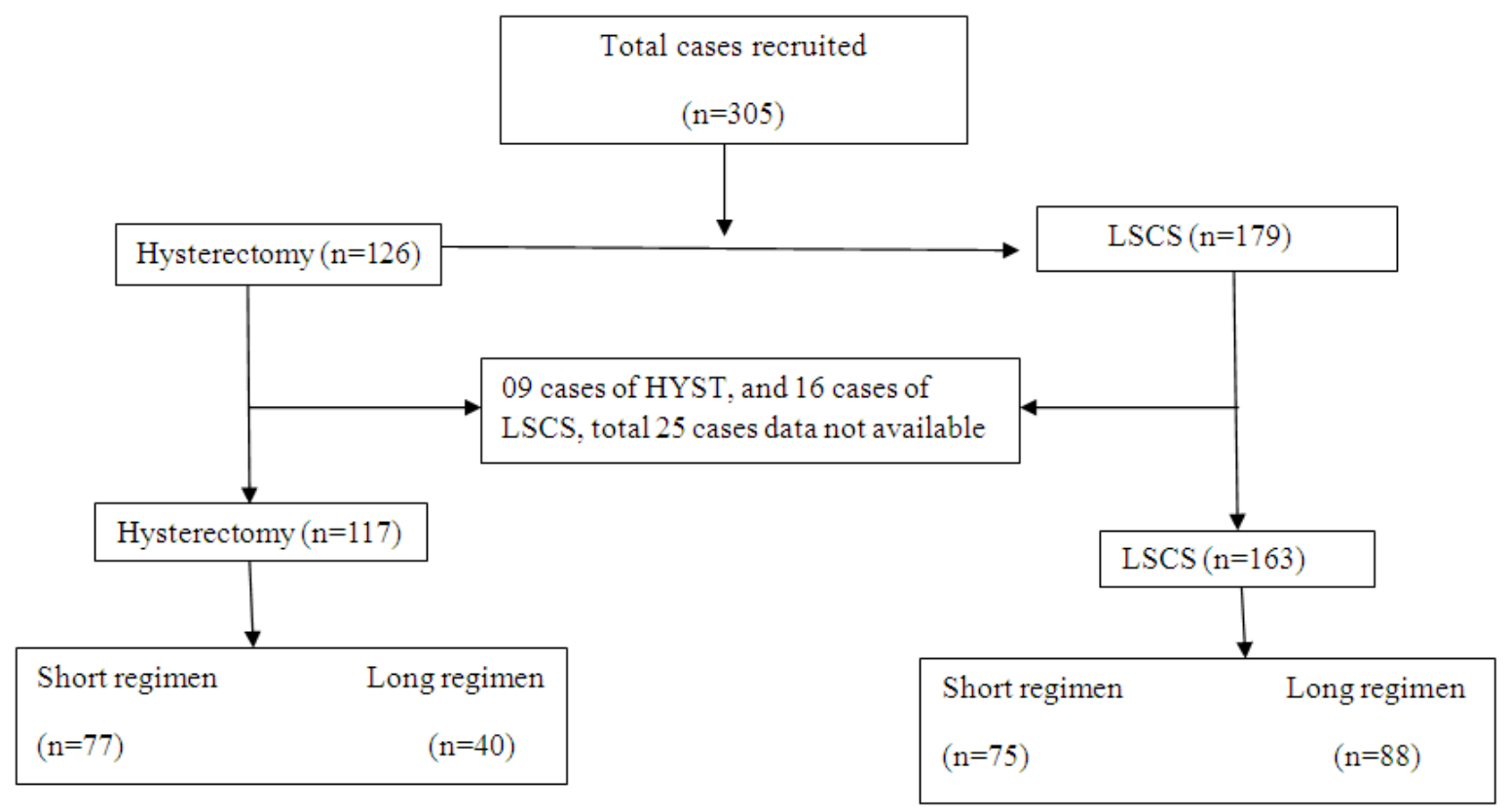

Figure 1: Distribution of cases.

Table 2: Average duration of antibiotics, total cost and average cost of antibiotics per patient between two regimens.

\begin{tabular}{|llllll|}
\hline Regimen & Operation & $\begin{array}{l}\text { No of } \\
\text { patients }\end{array}$ & $\begin{array}{l}\text { Average duration } \\
\text { of antibiotics per } \\
\text { patients in days }\end{array}$ & $\begin{array}{l}\text { Total cost of } \\
\text { antibiotics in Rs. }\end{array}$ & $\begin{array}{l}\text { Average cost } \\
\text { of antibiotics } \\
\text { per patients }\end{array}$ \\
\hline $\begin{array}{l}\text { Short } \\
\text { regimen }\end{array}$ & Hysterectomy & 77 & 1.5 day & 10969.05 & $\begin{array}{l}142.45 \\
\text { SD } \pm 177.91^{*}\end{array}$ \\
\cline { 2 - 6 } & LSCS & 75 & 1.57 day & 9230.99 & $\begin{array}{l}123.00 \\
\text { SD } \pm 94.29\end{array}$ \\
\hline $\begin{array}{l}\text { Long } \\
\text { regimen }\end{array}$ & Hysterectomy & 40 & 9.4 day & 50908.32 & $\begin{array}{l}1272.70 \\
\text { SD } \pm 1756.53 *\end{array}$ \\
\cline { 2 - 6 } & LSCS & 88 & 8.3 day & 59335.88 & $\begin{array}{l}674.27 \\
\text { SD } \pm 237.06\end{array}$ \\
\hline
\end{tabular}

*SD is bigger than average because cost range is very wide.

Table 3: Statistical analysis of cost of antibiotic used in hysterectomies.

\begin{tabular}{|c|c|c|c|}
\hline & & Mean \pm SD & $\begin{array}{l}\text { T test } \& \\
\text { P value }\end{array}$ \\
\hline \multirow[b]{2}{*}{ Hysterectomies } & $\begin{array}{l}\text { Short } \\
\text { course }\end{array}$ & $142.45 \pm 177.91$ & \multirow{2}{*}{$\begin{array}{l}\mathrm{T} \text { Test } \\
5.61 \\
\mathrm{P}<0.000 \\
\text { (the } \\
\text { difference } \\
\text { in cost is } \\
\text { statisticall } \\
\mathrm{y} \\
\text { significan } \\
\mathrm{t} \text { ) }\end{array}$} \\
\hline & $\begin{array}{l}\text { Long } \\
\text { course }\end{array}$ & $1272.70 \pm 1756.53$ & \\
\hline
\end{tabular}

Table 4: Statistical analysis of cost of antibiotic used in cesarean section.

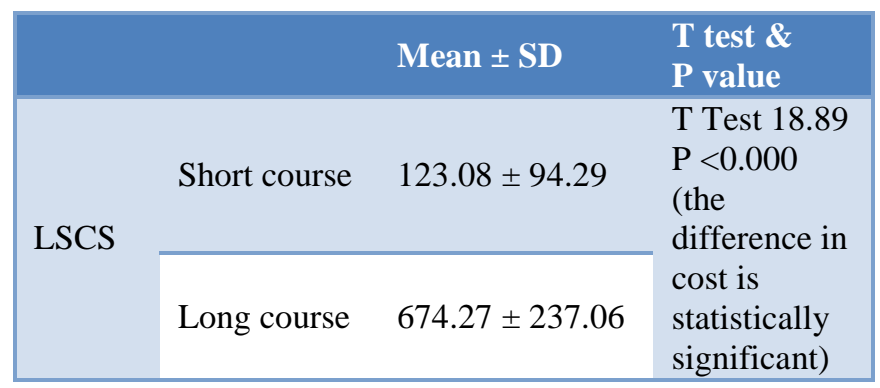


Table 5: Wound infection rate in percentage between two regimens.

\begin{tabular}{|c|c|c|c|c|}
\hline \multirow[b]{2}{*}{ Wound } & \multicolumn{2}{|c|}{$\begin{array}{l}\text { Hysterectomies } \\
(\mathrm{n}=117)\end{array}$} & \multicolumn{2}{|c|}{ LSCS (n=163) } \\
\hline & $\begin{array}{l}\text { Short } \\
\text { regimen } \\
(n=77)\end{array}$ & $\begin{array}{l}\text { Long } \\
\text { regimen } \\
(n=40)\end{array}$ & $\begin{array}{l}\text { Short } \\
\text { regimen } \\
(n=75)\end{array}$ & $\begin{array}{l}\text { Long } \\
\text { regimen } \\
(\mathrm{n}=\mathbf{8 8})\end{array}$ \\
\hline $\begin{array}{l}\text { Wound } \\
\text { gape }\end{array}$ & $\begin{array}{l}01 \\
(1.29 \%)\end{array}$ & $\begin{array}{l}4 \\
(10 \%)\end{array}$ & $\begin{array}{l}00 \\
(0 \%)\end{array}$ & $\begin{array}{l}01 \\
(1.13 \%)\end{array}$ \\
\hline $\begin{array}{l}\text { Serous } \\
\text { discharge }\end{array}$ & $00(0 \%)$ & $\begin{array}{l}05 \\
(12.5 \%)\end{array}$ & $\begin{array}{l}01 \\
(1.33 \%)\end{array}$ & $\begin{array}{l}03 \\
(3.40 \%)\end{array}$ \\
\hline $\begin{array}{l}\text { Purulent } \\
\text { discharge }\end{array}$ & $\begin{array}{l}01 \\
(1.29 \%)\end{array}$ & $\begin{array}{l}01 \\
(2.5 \%)\end{array}$ & $\begin{array}{l}00 \\
(0 \%)\end{array}$ & $\begin{array}{l}01 \\
(1.13 \%)\end{array}$ \\
\hline
\end{tabular}

Table 6: Outcome of wound infection of hysterectomies between two regimens.

\begin{tabular}{|llll|}
\hline Wound outcome & \multicolumn{3}{l}{ Hysterectomies } \\
& $\begin{array}{l}\text { Short } \\
\text { course }\end{array}$ & $\begin{array}{l}\text { Long } \\
\text { course }\end{array}$ & Significance \\
\hline Wound gape & 1 & 4 & $\mathrm{X} 2=2.64$ \\
\hline Serous discharge & 0 & 5 & $\mathrm{df}=2$ \\
\hline Purulent discharge & 1 & 1 & $\mathrm{P}>0.05^{*}$ \\
\hline
\end{tabular}

*The outcome/rate of wound infection in two regimens is not statistically significant.

Table 7: Outcome of wound infection of cesarean section between two regimens.

\begin{tabular}{|llll|}
\hline Wound outcome & $\begin{array}{l}\text { LSCS } \\
\text { Short } \\
\text { course }\end{array}$ & $\begin{array}{l}\text { Long } \\
\text { course }\end{array}$ & Significance \\
\hline Wound gape & 0 & 1 & $\mathrm{X} 2=0.60$ \\
\hline Serous discharge & 1 & 3 & $\mathrm{df}=2$ \\
\hline Purulent discharge & 0 & 1 & $\mathrm{P}>0.05^{*}$ \\
\hline
\end{tabular}

*The outcome/rate of wound infection in two regimens is not statistically significant.

\section{DISCUSSION}

Any antibiotic is effective in clean and uncontaminated cases and choice should be therefore based on other factors, such as cost. ${ }^{4}$

We have used narrow spectrum low cost cephalosporin, cefotaxime and metronidazole in short course antibiotic regimen. In short course regimen average duration of antibiotics was 1.5 days and 1.57 days for hysterectomy and LSCS respectively (Table 2). We found that short course regimen was as effective as long course regimen.

Parulekar et al. concluded that single dose cefotaxime is more effective as compared to conventional 5 days gentamicin and cloxacillin combination. ${ }^{5}$

\section{CONCLUSIONS}

No statistical difference as regard wound infection and febrile morbidity in short course and long course of prophylactic antibiotic therapy in cesarean section and hysterectomy (Table $6 \& 7$ ).

There is statistical difference in antibiotic cost between two regimen, short course and long course for cesarean section and hysterectomy (Table $3 \& 4$ ).

The cost of antibiotic is 5.53 times less in short course regimen for cesarean section and hysterectomy when compared with long course regimen.

\section{Funding: No funding sources}

Conflict of interest: None declared

Ethical approval: The study was approved by the institutional ethics committee

\section{REFERENCES}

1. ACOG. Practice bulletin on antibiotic prophylaxis. J Obstet Gynaecol. 2009;113:1180-9.

2. Berek S. Berek \& Novak's Gynecology. 14th Edition. Lippincott Williams \& Wilkins; 2007.

3. Schorge JO, Schaffer JI, Halvorson LM, Hoffman BL, Bradshaw KD, Cunningham FG. In: Schorge JO, Schaffer JI, editors. Williams Gynecology. New York, NY: McGraw Hill; 2008.

4. Chelmow D, Ruheli MS, Haung E. Prophylactic use of antibiotics for non labouring women undergoing for LSCS. Am J Obstet Gynaecol. 2001;184:656-61.

5. Parulekar P, Kumar S, Awasthi RT, et al. A single dose of cefotaxime: as a prophylaxis during cesarean section. J Obstet Gynaecol India. 2001;51:118-21.

6. Joseph T. Dipiro, Richard P. Cheung, Talmadge A. Bowden, John A. Mansberger. Single dose systemic antibiotic prophylaxis of surgical wound infection. Am J Surg. 1986;152:552-9.

7. Indian Drug Review (IDR). Drug triple i compendium. UBM Medicaindia Private Limited, Bangalore. 2013;XIX(5):268.

DOI: $10.5455 / 2320-1770$. ijrcog20140622

Cite this article as: Valvi AM, Mahale AR, Baravkar PN. How much antibiotic for cesarean section and hysterectomy: short course versus long course. Int J Reprod Contracept Obstet Gynecol 2014;3:394-7. 